\title{
Dapsone-resistant leprosy in Jakarta: a preliminary report
}

\author{
R UTJI,* A KOSASIH† \& A U S SANTOSO* \\ *Department of Microbiology, Medical Faculty, University of \\ Indonesia, Jakarta, Indonesia; †Department of Dermato-Venereo- \\ logy, Central General Hospital, Jakarta, Indonesia
}

Summary In a first effort to demonstrate the emergence of dapsone-resistant Mycobacterium leprae in Indonesia, 1 case of secondary resistance and 1 of primary resistance were demonstrated by inoculation of the mouse foot-pad.

Since 1969, it has been the practice in Indonesia to treat leprosy patients with dapsone as monotherapy. Considering the increasing prevalence of resistance to dapsone now being reported from many leprosy endemic areas, ${ }^{1}$ it was to be expected that strains of Mycobacterium leprae resistant to dapsone would already have emerged in Indonesia. There appeared an urgent need to attempt to identify Indonesian patients with leprosy who harboured dapsone-resistant M. leprae, both to assist in the care of the patients, and to bring the problem to the attention of the authorities responsible for leprosy control. Therefore, at the end of 1980, the mouse foot-pad technique for cultivation of $M$. leprae was established in the Department of Microbiology of the Medical Faculty of the University of Indonesia, and a programme of dapsone-susceptibility testing was begun. Reported here are the results of the first 6 studies completed.

\section{Materials and methods}

Biopsy specimens were obtained from lesions of patients with multibacillary leprosy attending the Skin Clinic of the Central General Hospital in Jakarta, who were suspected of secondary or primary resistance to dapsone. Employing the technique described by Shepard, ${ }^{2,3}$ Mycobacterium leprae were recovered from each specimen, and $5 \times 10^{3}$ were inoculated into each right hind foot-pad of 40 CBA mice; 1 group of 10 mice was held as untreated controls, whereas the mice of the other groups were administered dapsone in the diet in concentrations of $0.0001,0.001$ and $0.01 \mathrm{~g}$ per $100 \mathrm{~g}$ diet. Beginning 5 months after inoculation, $M$. 
leprae were harvested at intervals of 1 month from the right hind foot-pads of 2 control mice, and from the right hind foot-pads of 2 mice of each treated group, when the average number of organisms per foot-pad reached $5 \times 10^{5}$ in control mice.

\section{Results}

The characteristics of the patients, and the results of inoculation of mice with $M$. leprae, are summarized in Table 1 . These data demonstrate that the organisms of 1 patient-patient A-failed to infect mice, and might therefore have been susceptible to dapsone, i.e. they had been killed in the patient in the course of treatment. Those of 3 additional patients $-\mathrm{S}, \mathrm{M}$ and $\mathrm{R}-$ multiplied in untreated but not in treated mice, and may therefore be concluded to have been fully susceptible to dapsone.

The $M$. leprae of 2 patients were resistant to dapsone. Those of patient $\mathrm{T}$ multiplied as well in all groups of treated mice as in the untreated mice, and may be considered to show a high degree of resistance. The $M$. leprae of patient 'I' may be seen to have multiplied only in untreated mice, and in the mice administered the lowest concentration of dapsone, whereas they did not multiply in the mice treated with dapsone in higher concentration.

Table 1. Characteristics of the patients, and the fate of their $M$. leprae in mice

\begin{tabular}{|c|c|c|c|c|c|c|c|c|c|c|}
\hline \multirow[b]{3}{*}{ Patient } & \multirow{3}{*}{\multicolumn{2}{|c|}{$\begin{array}{c}\text { Sex/age } \\
\text { (years) }\end{array}$}} & \multirow[b]{3}{*}{ Class } & \multirow[b]{3}{*}{$\mathrm{BI}$} & \multirow{3}{*}{$\begin{array}{l}\text { Date mice } \\
\text { inoculated }\end{array}$} & \multirow{3}{*}{$\begin{array}{c}\text { Time of } \\
\text { harvest } \\
\text { (days) }\end{array}$} & \multicolumn{4}{|c|}{ Average no. $M$. leprae per foot-pad $\left(\times 10^{5}\right)$} \\
\hline & & & & & & & \multicolumn{4}{|c|}{ Dapsone concentration $(\mathrm{g} \%)$} \\
\hline & & & & & & & 0 & $0 \cdot 0001$ & 0.001 & $0 \cdot 01$ \\
\hline S & $\mathrm{F}$ & 22 & $\mathrm{BL}$ & $3+$ & 8.12 .80 & 248 & $8 \cdot 7$ & $0 \cdot 20$ & $\mathrm{NM}^{*}$ & $0 \cdot 03$ \\
\hline $\mathrm{T}$ & M & 35 & $\mathrm{BL} / \mathrm{LL}$ & $5+$ & 26.2 .81 & 184 & $9 \cdot 7$ & $14 \cdot 0$ & $8 \cdot 3$ & $16 \cdot 0$ \\
\hline A & M & 29 & Histoid & $5+$ & 26.2 .81 & 216 & NM & NM & NM & NM \\
\hline I & M & 14 & Histoid & $3+$ & 20.3.81 & 188 & $6 \cdot 8$ & $2 \cdot 1$ & NM & NM \\
\hline M & M & 35 & Histoid & $6+$ & 5.5 .81 & 322 & $3 \cdot 1$ & NM & NM & NM \\
\hline $\mathrm{R}$ & M & 52 & Histoid & $3+$ & 1.9 .81 & 188 & 4.8 & $0 \cdot 60$ & $0 \cdot 50$ & $0 \cdot 20$ \\
\hline
\end{tabular}

* No multiplication.

\section{Discussion}

In a first attempt to demonstrate the presence of dapsone-resistant $M$. leprae in Indonesia, the susceptibility to dapsone was measured of the organisms of 6 patients clinically suspected of resistance to dapsone. The organisms of 3 patients 
were fully susceptible, and those of an additional patient failed to infect mice, and may therefore be considered also to have been susceptible to dapsone. $M$. leprae of a high degree of resistance were isolated from 1 patient who had initially responded and subsequently relapsed after treatment with dapsone as monotherapy for years; this appears clearly to be an example of secondary resistance. Finally, low-degree resistance to dapsone was demonstrated in the case of a 14-year-old boy who denied previous treatment, and who therefore appears to represent an instance of primary resistance. Although one may be reluctant to base a diagnosis of primary resistance on the statement of a patient that he has received no previous treatment, the patient's statement is in this case reinforced by his youth; he does not appear to have lived long enough to have been treated with dapsone, responded and subsequently relapsed with secondary resistance.

\section{Acknowledgement}

This work received partial support from the Research Capability Strengthening (RCS) component of the UNDP/World Bank/WHO Special Programme for Research and Training in Tropical Diseases, in the form of participation in the Mouse Foot-Pad Technique Standardization and Application Workshop, Chingleput, South India, 19 November-14 December 1979, and of a 're-entry' grant. The authors wish also to acknowledge the gift of a breeding nucleus of CBA mice from the Research Unit, Sungei Buloh Leprosarium, Selangor, Malaysia.

\section{References}

1 Pearson, JMH. The problem of dapsone resistant leprosy. Int J Lepr, 1981; 49: 417-26.

${ }^{2}$ Shepard CC. The experimental disease that follows the injection of human leprosy bacilli into foot-pads of mice. $J$ exp Med, 1960; 112: 445-54.

${ }^{3}$ Shepard CC, McRae DH. A method for counting acid-fast bacteria. Int J Lepr, 1968; 36: 78-82. 